\title{
Horticulture affects macroinvertebrate assemblages in adjacent streams (Buenos Aires, Argentina)
}

\author{
Marina Arias ${ }^{1, *}$, Ana Scalise ${ }^{1}$, Marina Solis ${ }^{1}$, Ariel Paracampo ${ }^{1}$, Mercedes Indaco ${ }^{2}$, Silvia Fanelli $^{1}$, \\ Hernán Mugni ${ }^{1}$ and Carlos Bonetto ${ }^{1}$ \\ ${ }^{1}$ Instituto de Limnología Dr. Raúl A. Ringuelet (ILPLA), UNLP - CONICET - FCNyM, Boulevard 120 y 62 S/N, 1900, La Plata, \\ Buenos Aires, Argentina \\ ${ }^{2}$ Centro de Investigaciones en Toxicología Ambiental y Agrobiotecnología del Comahue (CITAAC), CONICET, Universidad Nacional \\ del Comahue, Buenos Aires N1400, 8300 Neuquén Capital, Neuquén, Argentina
}

Received: 24 June 2019 / Accepted: 15 December 2019

\begin{abstract}
The agrochemicals used on crops can reach watercourses, affecting water quality and biologic communities. The aim of this research was to study the effects of horticulture on the water quality and invertebrate assemblages of adjacent streams in Buenos Aires province, Argentina. Four streams draining horticultural basins were compared with another four considered less disturbed: two of the latter located in a Biosphere Reserve and the other two in extensive livestock-raising basins. Pesticides were detected in the horticulture-related streams, while nutrient concentrations were significantly higher than in the lessdisturbed streams. The macroinvertebrate assemblages differed: the less-disturbed streams exhibited a significantly higher taxa richness and density. Hyalella sp. and Simocephalus vetulus were dominant, whereas Entomobryoidea, Dugessidae, and Glossiphoniidae were dominant in the horticultureassociated streams. Ephemeroptera (Caenis and Baetidae) were well represented in the less-disturbed streams and rare or absent in the horticulture-adjacent streams. Multivariate analysis indicated that the horticulture-impacted sites contained high nutrient concentrations and tolerant taxa, while the lessdisturbed sites corresponded to lower nutrient concentrations and sensitive taxa. We propose Hyalella sp. and $S$. vetulus as water-quality indicators in pampean streams and conclude that intensive agrochemical applications in horticulture increase nutrient and pesticide loads affecting the macroinvertebrate assemblages of adjacent streams.
\end{abstract}

Keywords: Land use / agrochemicals / freshwater / communities

Résumé - L'horticulture affecte les communautés de macroinvertébrés dans les cours d'eau drainants (Buenos Aires, Argentine). Les produits agrochimiques utilisés sur les cultures peuvent atteindre les cours d'eau, affectant la qualité de l'eau et les communautés biologiques. Le but de cette recherche était d'étudier les effets de l'horticulture sur la qualité de l'eau et les assemblages d'invertébrés des cours d'eau adjacents dans la province de Buenos Aires en Argentine. Quatre cours d'eau drainant des bassins horticoles ont été comparés à quatre autres jugés moins perturbés : deux d'entre eux situés dans une réserve de biosphère et les deux autres dans de vastes bassins d'élevage. Des pesticides ont été détectés dans les cours d'eau liés à l'horticulture, tandis que les concentrations de nutriments étaient considérablement plus élevées que dans les cours d'eau moins perturbés. Les assemblages de macroinvertébrés différaient : les cours d'eau moins perturbés présentaient une richesse et une densité taxonomiques nettement plus élevées. Hyalella sp. et Simocephalus vetulus dominaient, tandis que les Entomobryoidea, Dugessidae et Glossiphoniidae dominaient dans les ruisseaux associés à l'horticulture. Les éphéméroptères (Caenis et Baetidae) étaient bien représentés dans les cours d'eau moins perturbés et rares ou absents dans les cours d'eau voisins de l'horticulture. L'analyse multivariée indique que les sites touchés par l'horticulture contenaient des concentrations élevées d'éléments nutritifs et des taxons tolérants, tandis que les sites moins perturbés correspondaient à des concentrations inférieures d'éléments nutritifs et à des taxons sensibles. Nous proposons Hyalella sp. et S. vetulus comme

\footnotetext{
*Corresponding author: marinaarias7@gmail.com
} 
indicateurs de la qualité de l'eau dans les cours d'eau pampéens et concluons que les applications agrochimiques intensives en horticulture augmentent les charges de nutriments et de pesticides affectant les communautés de macroinvertébrés des cours d'eau voisins.

Mots-clés : Utilisation des terres / produits agrochimiques / eau douce / communautés

\section{Introduction}

Horticulture is the main farming activity worldwide following cereal production (FAO, 2013). In Argentina, horticultural production is established mainly in the surroundings of the large cities in order to supply food for urban consumption. The horticultural area around La Plata city is located in the northeast of the Buenos Aires province, where $35 \%$ of Argentina's population lives. The area measures 3746 hectares and produces 78,360 tons per year (CHFB, 2005). This high productivity is based on an intensive input-dependent fieldcropping system along with greenhouse technology. Fertilizers and pesticides are heavily used to raise crop yields.

Fertilizer consumption in Argentina was 3,121,638 tons in 2014 (CIAFA, 2017), while the annual use of pesticides reached some 336,000 tons in 2011 (CASAFE, 2013). As many as one hundred sixty different pesticides - comprising fungicides, herbicides and insecticides - are used in the area (Sarandón et al., 2015). Endosulfan, cypermethrin, and chlorpyrifos were the most widely used insecticides in Argentina until 2013, when the first of those was banned (SENASA, 2011). At present, cypermethrin and chlorpyrifos represent the most extensively employed insecticides.

Agrochemicals used in crops can reach surface watercourses by spray drift or runoff. The latter transports nutrients (Hart et al., 2004) along with pesticides (Jergentz et al., 2005) from crops to the adjacent streams; the latter input then produces ephemeral toxicity pulses to non-target organisms (Mugni et al., 2011; Schulz, 2001). Several studies have linked pesticide exposure to changes in macroinvertebrate-community structure, most commonly in the form of the disappearance or decreased density of sensitive taxa (Liess et al., 2008; Egler et al., 2012; Schäfer et al., 2012). The differential sensitivity of invertebrates to pesticides could accordingly be used as a biomonitoring tool to assess the condition of aquatic systems (Liess and von der Ohe, 2005). Schäfer et al. (2007) reported that pesticides affected leaf-litter breakdown because the shredders numbered among the sensitive species; thus pesticide exposure can not only impair communities but also affect stream functions.

Agricultural land use affects macroinvertebrate assemblages in regional streams, resulting in the disappearance or decreased abundance of sensitive groups such as Odonata and Ephemeroptera (Jergentz et al., 2004) or Amphipoda (Solis et al., 2016). Agricultural land use has been found to increase nutrient concentrations in pampean streams (Mugni et al., 2013). Enhanced primary production coupled with toxic effects on the consumers would increase eutrophication in horticulture-affected streams (Frieberg Jensen et al., 2003; Relyea, 2004).

The information on pesticide concentrations in horticulture watersheds is scarce (Kreuger et al., 2008; Allinson et al., 2014; Mottes et al., 2017). Only few studies have monitored the levels of those xenobiotic and the consequent toxicity to aquatic organisms in the La Plata horticultural belt (Mac Loughlin et al., 2017; Rimoldi et al., 2018). Solis et al. (2018) compared the assemblage composition in streams influenced by agriculture or livestock and within a reserve. One of the streams considered to be affected by agriculture included areas with adjacent horticulture in the basin. The effect of horticulture on the composition of the non-target resident fauna in the region, however, remained largely unreported.

The aim of this study was therefore to assess the effect of horticultural land use on the macroinvertebrate assemblages of adjacent streams in the Buenos Aires province of Argentina. We hypothesized that the application of agrochemicals altered the macroinvertebrate assemblages of adjacent streams.

\section{Materials and methods}

\subsection{Study area and sampling design}

Eight lowland streams were studied in the Rio de la Plata coastal fringe in the environs of La Plata and Magdalena, Buenos Aires province, Argentina (Fig. 1). The study area is located within the pampa plain, an extensive area of extremely low relief with slopes typically around $0.15 \%$ (Hurtado et al., 2006) comprising grasslands with small patches of forest. The baseline stream flow remains imperceptible most of the time except after rainfalls. The streams are shallow $(10-50 \mathrm{~cm}$ in depth) with beds containing mainly fine sediments (43\% silt, $25 \%$ clay, and $32 \%$ sand), lacking boulders or gravel, and having an abundant litter content. The streams lack forested borders; instead, conspicuous macrophytes and abundant riparian vegetation are developed. The climate is mild-humid with a mean annual air temperature of $16^{\circ} \mathrm{C}$, ranging from $10^{\circ} \mathrm{C}$ in July to $23^{\circ} \mathrm{C}$ in January. The mean annual precipitation is roughly $1000 \mathrm{~mm}$, being the highest in March (111 mm) and the lowest in June (63 mm; Hurtado et al., 2006).

We sampled four streams - San Juan, Martín, Gato, and Sauce - which drain basins located within the horticultural belt around La Plata city, along with another four that were less disturbed: two, Morales and Destino, run through the Parque Costero Sur, UNESCO Biosphere Reserve (Athor, 2009); the other two, unnamed and Buñirigo, drain basins with extensive livestock on natural grasslands. Solis et al. (2018) had reported the macroinvertebrate-assemblage composition in the reserve and livestock streams as not being significantly different.

The streams were sampled in two successive crop-growing seasons, coinciding with the main agrochemical-application period, from spring (October) to mid-autumn (April). The first period comprised five samplings, in October and December 2014 and January, March, and May 2015; the second consisted of two samplings, in October and December 2015. The sampling was discontinued in January 2016 because of a strong drought. 


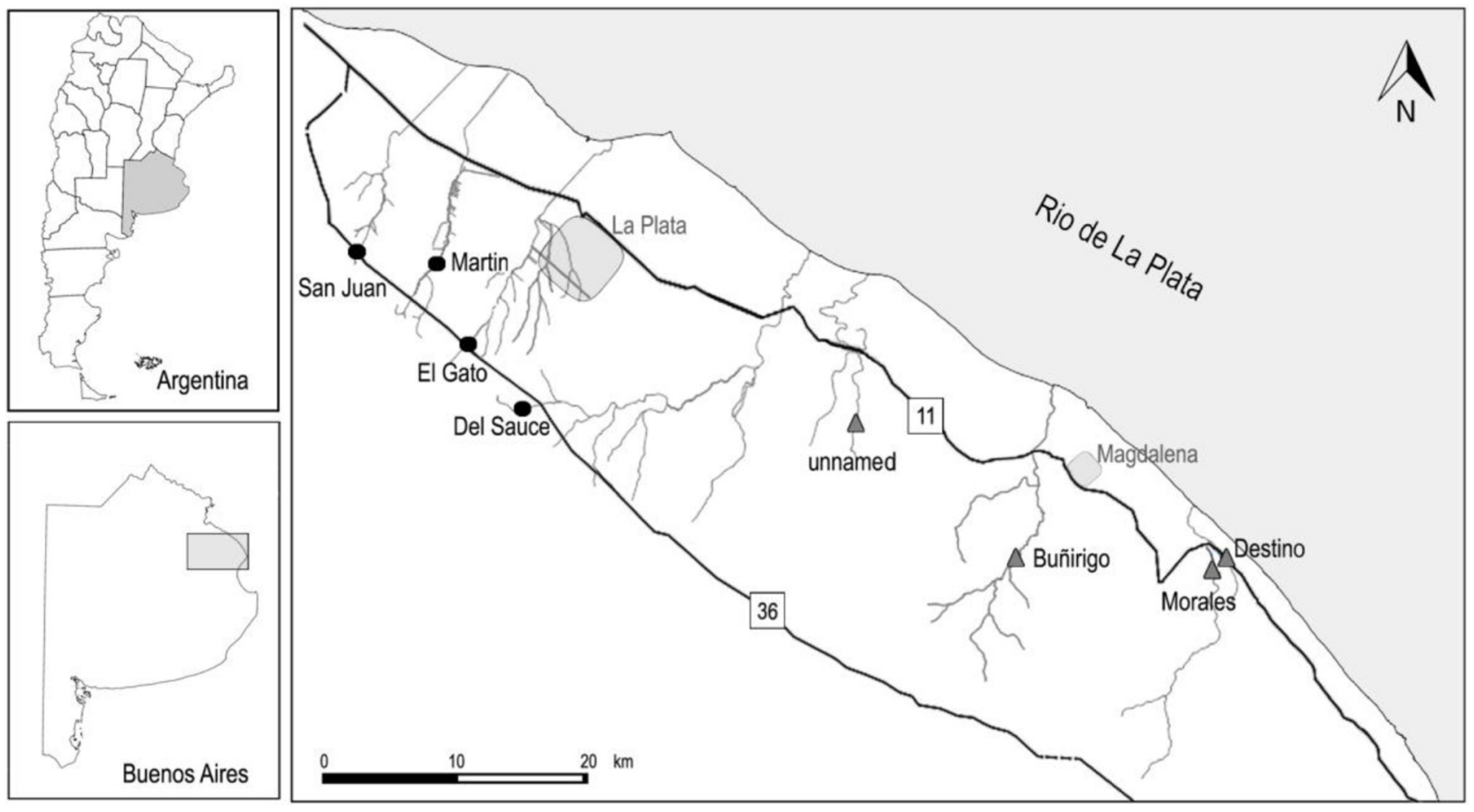

Fig. 1. Study area illustrating the location of the sampling sites in relation to La Plata. The upper inset indicates the location of the Province of Buenos Aires within Argentina, the lower inset the position of the sampling area within the province. Circles, horticulture-associated sampling sites; triangles, less-disturbed sampling sites.

\subsection{Environmental variables and nutrient concentrations}

At each sampling site, the dissolved-oxygen concentration (DO) and temperature $\left(\mathrm{T}^{\circ}\right)$ were measured in situ with an YSI 51B, the $\mathrm{pH}$ with a Hanna Checker, and the conductivity with Hanna Instrument 8733. Water samples were taken in triplicate and transported to the laboratory in coolers covered with ice. In the laboratory, the samples were filtered through a Whatman GF/C filter. The nutrients were then measured in the filtrate: the soluble reactive phosphorus (SRP) was determined by a colorimetric reaction with ascorbic-acidammonium-molybdate, the nitrate by hydrazine reduction followed by diazotation, and the ammonium by the indophenol-blue method (APHA, 2012). The suspended matter was estimated as the weight difference of the filter before and after filtration (APHA, 2012). Chlorophyll was acetone-extracted from the dry filters for $24 \mathrm{~h}$, under refrigeration, following Lorenzen (1967).

The sediment samples were taken from the top two centimeters with a stainless-steel scoop and placed in glass vessels. The samples were immediately kept on ice until arrival at the laboratory, where they were then stored at $-20^{\circ} \mathrm{C}$ until the time of pesticide analysis. The organic carbon in the sediment was assessed by weight loss after drying at $105{ }^{\circ} \mathrm{C}$ followed by heating to $550^{\circ} \mathrm{C}$ for $2 \mathrm{~h}$ (Olivier et al., 2001). The percentage of vegetation cover was estimated visually (Dethier et al., 1993) - in a $1-\mathrm{m}^{2}$ quadrant, divided into four equal quadrants - before invertebrate sampling.

\subsection{Pesticides}

We assessed the most commonly used pesticides and certain others selected among those previously reported to be found at higher detection frequencies in the region (Hunt et al., 2016; Solis et al., 2017) - namely, the organochlorines $\alpha-, \omega-, \beta-$, and $\delta$-benzene hexachloride; heptachlor and heptachlor epoxide; aldrin; dieldrin; endrin and endrin aldehyde; methoxychlor; $\alpha-, \beta$-, and $S$ endosulfan; the dichlrodiphenyltrichloroethanes (aka DDTs) p, p'-3, 3-dimethyl-4-pentenoic acid methyl ester (DPE), p, p'-dichlrodiphenyldichloroethylene (DDE), and p, p'-dichlrodiphenyldichloroethane (DDD); the organophosphate chlorpyrifos; and finally the pyrethroids $\lambda$-cyhalothrin, permethrin, the cypermethrins (mixture of isomers), fenvalerate, and deltamethrin. Because of the hydrophobicity of these compounds, the pesticides are adsorbed onto the particulate fraction of these streams and therefore the analysis was conducted on only the sediment samples in order to increase the detection frequency.

The sediment samples were extracted following You et al. (2004) with a mixture of acetone and methylene chloride. A clean-up procedure was carried out through the use of Florisil solid-phase-extraction cartridges.

The sample extracts $(1 \mathrm{ml}$ in hexane) were injected for organophosphate-residue determination in a gas chromatograph with nitrogen-phosphorus detection and for organochlorine $(\mathrm{OCl})$ and pyrethroid $(\mathrm{Py})$ residues in a gas chromatograph with an electronic-microcapture detector. The quantitation was 
performed by comparison with external standards. The organophosphate residues were confirmed by tandem gas chromatography-mass spectrometry, and the $\mathrm{OCl}$ and $\mathrm{Py}$ residues by injection in a column of a different polarity.

An Agilent 6890 gas chromatograph equipped with an Agilent 7683 autosampler; split/splitless injector; a capillary column, HP $5(30 \mathrm{~m}$ in length, $0.25 \mathrm{~mm}$ i.d., $0.25 \mu \mathrm{m}$ film thickness); and a nitrogen-phosphorus detector was used for the quantitation of the organophosphate compounds (detector temperature, $300^{\circ} \mathrm{C}$; oven-temperature program, $70-240^{\circ} \mathrm{C}$; injector temperature, $250{ }^{\circ} \mathrm{C}$; injection volume, $1 \mu \mathrm{l}$; carrier gas, $\mathrm{N}_{2}$ ). An Agilent $6890 \mathrm{~N}$ gas chromatograph equipped with an Agilent 7683B autosampler, split/splitless injector and a capillary column, HP 5MS/DB17 (30 $\mathrm{m}$ in length, $0.25 \mathrm{~mm}$ i. d., $0.25 \mu \mathrm{m}$ film thickness) with an electronic microcapture detector was used for the quantitation of the $\mathrm{OCl}$ and $\mathrm{Py}$ compounds (detector temperature, $300^{\circ} \mathrm{C}$; oven-temperature program, $70-240{ }^{\circ} \mathrm{C}$; injector temperature, $250{ }^{\circ} \mathrm{C}$; injection volume, $1 \mu \mathrm{l}$; carrier gas, $\mathrm{N}_{2}$ ). The confirmation was performed by tandem gas chromatography-mass spectrometry (injection system, programmed-temperature vaporizing; injection volume, $5 \mu \mathrm{l}$; gas carrier, $\mathrm{He}$ ). The linearity of the calibration curves, measured by the determination coefficient $\left(R^{2}\right)$, was always $\geq 0.99$. The reference standards were from Accustandard (purity $>99 \%$ ) and the quantitation limits $0.7 \mathrm{ng} / \mathrm{g}$ dry weight ( $\mathrm{dw}$ ) for $\mathrm{OCl}, 0.9 \mathrm{ng} / \mathrm{g} \mathrm{dw}$ for chlorpyrifos, $4.5 \mathrm{ng} / \mathrm{g} \mathrm{dw}$ for other OPs, $9.1 \mathrm{ng} / \mathrm{g} \mathrm{dw}$ for cypermethrin, and $1.8-3.6 \mathrm{ng} / \mathrm{g} \mathrm{dw}$ for other pyrethroids.

\subsection{Macroinvertebrate assemblages}

The sampling was carried out with a $500-\mu \mathrm{m}$ D-net over aquatic vegetation inside a $1-\mathrm{m}^{2}$ floating polyvinyl chloride quadrant, which method enabled us to compare the same surface among sampling sites. The samples were taken in triplicate, fixed in situ with $96 \%$ (v/v) aqueous ethanol, and subsequently processed in the laboratory; where the organisms were counted and identified to the lowest possible taxonomic level with a stereoscopic Leica model EZ4 ${ }^{\mathrm{TM}}$ microscope and following general (Merrit et al., 2008) and regional (Domínguez and Fernández, 2009) taxonomic keys.

\subsection{Data analysis}

The differences between the horticulture-associated and the less-disturbed sites with respect to environmental variables, nutrients, and the detection frequency of pesticides were tested by the Student $t$ test. Whenever normality assumptions were not substantiated, the nonparametric Mann-Whitney $U$ test was used. All the statistical analyses were performed by means of the Sigma Plot 12.0 software at a significance level of $p<0.05$. The samples were grouped according to land use (horticultureaffected or less disturbed) and then compared. The detection frequency of the pesticides was calculated for each stream.

The taxonomic richness $(S)$ and density (ind $/ \mathrm{m}^{2}$ ) were calculated for each site at each sampling and then analyzed in the same way as the environmental variables. Differences in the assemblage composition were analyzed through ANOSIM (analysis of similarity) with the factor land use, by applying the Bray-Curtis Similarity Index. The density data were transformed by the $\log (x+1)$ function with those taxa present in only one sample being not considered (Clarke and Warwick, 2001). The SIMPER (percentage similarity) analysis was performed to determine which taxa contributed the most to the differences in the assemblage composition. The analyses were performed with the PRIMER version 6 software (Plymouth Routines Multivariate Ecological Research; Clarke and Gorley, 2001).

The relationships between taxa richness and density, nutrient concentrations, vegetation cover, and chlorophyll were determined by the Pearson correlation analysis; those between the environmental variables and the assemblage composition by the CANOCO version 4.53 software (ter Braak and Smilauer, 1998). The density data were $\log (x+1)$ transformed. Taxa with total relative abundance lower than $0.5 \%$ were excluded from the analysis to reduce the influence of rare species.

The maximum gradient length of macroinvertebrate data was determined by means of the detrended correspondence analysis. The maximum amount of variation in the speciesrichness data was 1.8 , indicating that linear statistical methods were appropriate. Consequently, a Redundancy Analysis (RDA) was carried out. All the variables except $\mathrm{pH}$ were normalized, and forward selection was used to determine the variables that significantly explained the distribution pattern of macroinvertebrates at a cutoff point of $p<0.05$. To subtract the effect of vegetation, a partial redundancy analysis was performed by entering the vegetation cover into the RDA as a covariable. The significance of the RDA axes was assessed by the Monte-Carlo permutation test.

\section{Results}

\subsection{Environmental variables and nutrient concentrations}

Table 1 summarizes the environmental variables and nutrient concentrations measured. No significant differences were observed in the environmental variables when the horticulture-affected and less-disturbed streams were compared. The nitrate, ammonium, and SRP concentrations were, however, significantly higher in the former than in the latter $(p<0.001, p=0.002, p<0.001)$. The mean nitrate concentrations were an order of magnitude higher, while the ammonium and SRP levels were three times higher in the streams adjacent to horticulture. The chlorophyll concentration correlated with both the SRP levels $(R=0.28, p=0.049)$ and the ammonium concentrations $(R=0.28, p=0.048)$.

\subsection{Pesticides}

Insecticides were generally not detected in the lessdisturbed streams, except chlorpyrifos and cypermethrin, which compounds were recorded in a single sampling (Tab. 2). Chlorpyrifos was detected at low concentrations $(1.5-5.8 \mathrm{ng} / \mathrm{g}$ $\mathrm{dw})$ in the less-disturbed Buñirigo Stream and those within the reserve in only December 2014, while cypermethrin was recorded (10-45 ng/g dw) in the Buñirigo and the also lessdisturbed unnamed stream in January 2015. The detection frequency was significantly higher $(p=0.023)$ in the horticulture-associated streams than in the less-disturbed streams (Tab. 2). 
Table 1. Environmental variables and nutrient concentrations in the studied streams. Mean values and (variation range).

\begin{tabular}{|c|c|c|}
\hline \multirow[t]{2}{*}{ Variables } & \multicolumn{2}{|c|}{ Studied streams } \\
\hline & Horticulture-associated & Less-disturbed \\
\hline$T\left({ }^{\circ} \mathrm{C}\right)$ & $19.8(12-30)$ & $22.3(12-29)$ \\
\hline Conductivity (Cond.) $(\mu \mathrm{S} / \mathrm{cm})$ & $502(110-853)$ & $687(83-1330)$ \\
\hline Dissolved oxygen (OD) (mg/L) & $6.7(1.3-19)$ & $6.8(2.5-10.6)$ \\
\hline $\mathrm{pH}$ & $7.7(6.6-9.3)$ & $7.8(6.9-9.2)$ \\
\hline Depth $(\mathrm{cm})$ & $23(5-50)$ & $34(11-63)$ \\
\hline Suspended matter $(\mathrm{SM})(\mathrm{mg} / \mathrm{L})$ & $103(2-1208)$ & $105(13-457)$ \\
\hline Sediment Organic Carbon (OC\%) & $3.9(1-7)$ & $3.7(1-9)$ \\
\hline Chlorophyll $(\mu \mathrm{g} / \mathrm{L})$ & $45(4-355)$ & $24(3.5-82)$ \\
\hline Vegetation cover (VEG) $(\%)$ & $62(15-100)$ & $58(17-90)$ \\
\hline $\operatorname{SRP}(\mu \mathrm{g} / \mathrm{L})$ & $319(84-765)$ & $109(16-434)$ \\
\hline Nitrate $\left(\mu \mathrm{g} \mathrm{N}-\mathrm{NO}_{3}{ }^{-} / \mathrm{L}\right)$ & $1183(20-6808)$ & $95(2-367)$ \\
\hline Ammonium $\left(\mu \mathrm{g} \mathrm{N}-\mathrm{NH}_{4}{ }^{+} / \mathrm{L}\right)$ & $229(16-1334)$ & $71(4-414)$ \\
\hline
\end{tabular}

Table 2. Detected pesticides in the studied streams (ng/g dry weight).

\begin{tabular}{|c|c|c|c|c|c|c|}
\hline & DF & Chlorpyrifos & L-Cyhalothrin & Cypermethrin & pp'DDT & pp'DDD \\
\hline \multicolumn{7}{|c|}{ HORTICULTURE } \\
\hline San Juan & 0.29 & & & & & \\
\hline May 2015 & & nd & nd & nd & nd & 1.8 \\
\hline Dec. 2015 & & nd & nd & nd & nd & 2.2 \\
\hline Martin & 0.60 & & & & & \\
\hline Dec. 2014 & & 0.9 & nd & nd & nd & nd \\
\hline Jan. 2015 & & nd & nd & 6.4 & nd & nd \\
\hline Oct. 2015 & & nd & nd & nd & nd & 0.8 \\
\hline Gato & 0.43 & & & & & \\
\hline Jan. 2015 & & nd & 0.9 & 148 & nd & nd \\
\hline May 2015 & & nd & nd & 199 & nd & nd \\
\hline Dec. 2015 & & nd & nd & nd & 4 & nd \\
\hline Sauce & 0.43 & & & & & \\
\hline Jan. 2015 & & nd & nd & 14 & nd & nd \\
\hline May 2015 & & nd & nd & nd & nd & 1.9 \\
\hline Dec. 2015 & & nd & nd & 51 & 2 & nd \\
\hline \multicolumn{7}{|c|}{ LESS DISTURBED } \\
\hline unnamed & 0.2 & & & & & \\
\hline Jan. 2015 & & nd & nd & 18.7 & nd & nd \\
\hline Buñirigo & 0.29 & & & & & \\
\hline Dec. 2014 & & 1.5 & nd & nd & nd & nd \\
\hline Jan. 2015 & & nd & nd & 6.6 & nd & nd \\
\hline Morales & 0.25 & & & & & \\
\hline Dec. 2014 & & 3.4 & nd & nd & nd & nd \\
\hline Destino & 0.14 & & & & & \\
\hline Dec. 2014 & & 5.8 & nd & nd & nd & nd \\
\hline
\end{tabular}

DF: Detection frequency; nd: not detected. Samplings without at least one pesticide detected are not shown.

In contrast, cypermethrin evidenced a detection frequency of $20 \%$ in the horticulture-adjacent streams, attaining peak concentrations of $148-199 \mathrm{ng} / \mathrm{g} \mathrm{dw}$ in two consecutive samplings in the Gato Stream, and of $51 \mathrm{ng} / \mathrm{g} \mathrm{dw}$ in the Sauce Stream. Chlorpyrifos, lambda-cyhalothrin, DDT, and DDD were measured at low concentrations $(0.9-6 \mathrm{ng} / \mathrm{g} \mathrm{dw})$ only in the horticulture-associated streams.

\subsection{Macroinvertebrate assemblages}

A total of 30,829 specimens were counted and 88 taxa identified, representing 52 families and 18 orders (Supplementary Material, Tab. S1). Amphipoda and Copepoda were present at all the sites. Simocephalus vetulus and S. daphnoides (Daphniidae) along with the amphipod Hyalella sp. were the 
Table 3. SIMPER analysis showing average abundances (log transformed) of taxa for both land uses and contribution (\%) to $>30 \%$ of dissimilarity.

\begin{tabular}{lllll}
\hline \multirow{2}{*}{ Taxa } & \multicolumn{3}{c}{ Av. Abundances } \\
\cline { 2 - 5 } & Horticulture-associated & Less disturbed & Contribution (\%) & Cum. Cont. (\%) \\
\hline S. vetulus & 1.1 & 3.6 & 5.0 & 5.0 \\
Hyalella sp. & 1.9 & 3.8 & 4.7 & 9.7 \\
Baetidae & 0.1 & 2.2 & 4.0 & 13.7 \\
Dugesiidae & 2.5 & 0.3 & 3.8 & 17.6 \\
S. daphnoides & 0.6 & 2.5 & 3.8 & 21.3 \\
Ciclopoidea & 2.0 & 2.5 & 3.5 & 24.9 \\
Entomobryoidea & 3.3 & 1.9 & 3.4 & 28.2 \\
Caenis sp. & 0.0 & 1.7 & 3.2 & 31.4 \\
Hirudinea & 2.0 & 1.0 & 2.9 & 34.3 \\
\hline
\end{tabular}

most abundant in the less-disturbed streams except for the unnamed one, where cladocerans were dominant followed by Copepoda. The Trichoptera families Hydroptylidae and Polycentropodidae (Cyrnellus sp.) and the Decapoda were identified in only the less-disturbed streams. The Ephemeroptera likewise exhibited higher densities in the less-disturbed than in horticulture-associated streams, The Baetidae were rare and Caenis sp. was absent at the horticulture-adjacent sites. In contrast, the Collembolans (Entomobryoidea and Poduroidea) were commonly the most abundant taxa in horticultureinfluenced streams; while other dominant taxa were the Diptera, the Dugessidae, and the Copepoda.

The taxonomic richness and density were significantly higher in the less-disturbed than in the horticulture-adjacent streams ( $p<0.001$ and $p=0.025$, respectively). An average of 35 taxa was recorded in the less-disturbed, as against 24 in the horticultur-associated streams. The mean density of the macroinvertebrates in the less-disturbed streams was almost twice that of the in horticulture-adjacent streams $\left(819 \mathrm{ind} / \mathrm{m}^{2}\right.$ versus $461 \mathrm{ind} / \mathrm{m}^{2}$, respectively). Among the less-disturbed streams, the unnamed was the one with the highest taxonomic richness (41 taxa) and Morales was the one with the highest density $\left(1286 \mathrm{ind} / \mathrm{m}^{2}\right)$. In contrast, of the 4 horticultureaffected streams, Martín was the one with the poorest abundance parameters at 18 taxa and $172 \mathrm{ind} / \mathrm{m}^{2}$ (Tab. S1). The mean densities of the crustaceans Hyalella sp. and $S$. vetulus were significantly higher in the less-disturbed (239 and $136 \mathrm{ind} / \mathrm{m}^{2}$, respectively) than in the horticulture-influenced streams $\left(25\right.$ and $13 \mathrm{ind} / \mathrm{m}^{2}, p=0.04$ and $p<0.001$, respectively).

The vegetation cover was positively correlated with the taxa richness and the macroinvertebrate density $(R=0.35$, $p=0.015$ and $R=0.45, p=0.001$, respectively). The richness was inversely correlated with the SRP $(R=-0.33, p=0.021)$ and the ammonium $(R=-0.32, p=0.024)$, while the population density was likewise inversely correlated with the SRP concentrations $(R=-0.42, p=0.002)$.

\subsection{Macroinvertebrate assemblages}

The assemblage composition of the horticulture-adjacent and the less-disturbed streams was significantly different (ANOSIM: Global $R=0.45 ; p=0.001$; factor: "land use"). The
SIMPER analysis indicated an average dissimilarity of $68 \%$ between the two groups. The taxa that contributed most to the dissimilarity (Tab. 3) were S. vetulus, Hyalella sp., and the Baetidae - those being well represented in the less-disturbed streams - and Caenis because of that genus's absence in horticulture-associated streams. The Dugessidae, Entomobyridae, and Glossiphoniidae contributed to the differences because of their comparatively high abundance in the horticulture-affected streams.

The redundancy analysis revealed that vegetation cover, SRP, DO, conductivity, ammonium, and the percent organic carbon explained $32 \%$ of the total variability in the macroinvertebrate-assemblage composition. The global significance test for the first canonical axis and the sum of all axes was significant $(F$ ratio $=6.768 ; p=0.002$ and $F$ ratio $=2.260 ; p=0.002$, respectively). Since the vegetation cover did not differ significantly among the different land uses, that influence was considered separately; a partial RDA analysis was performed involving vegetation cover as a covariable. This RDA explained $23 \%$ of the variance. The first and second axes accounted for $75 \%$ of the relationship between species and the environment. The first axis was correlated with the SRP (0.60), ammonium concentration (0.41) and the percent organic carbon (0.04); the first two of those variables being higher in the horticulture-associated streams and as such representing an environmental-deterioration gradient. The second axis was positively correlated with DO (0.66) and the percent organic carbon (0.06) and negatively with the conductivity $(-0.33)$. In the diagram of the sampling sites (Fig. 2a), those associated with horticulture were located on the right side of the ordination and were related to high SRP and ammonium concentrations; the lessdisturbed sites were located on the left side of the diagram and were accordingly negatively correlated with the SRP and ammonium concentrations. A correspondence between the abundance of certain taxa and the gradients was also observed (Fig. 2, Panel b.). The Entomobryoidea, Poduroidea, Glossiphonidae, Dugessidae, Paracymus, Pomacea, and Enochrus were positively correlated with nutrient concentrations - pointing to agrochemical contamination in the horticulture-adjacent streams - whereas Hyalella sp., Simocephalus sp., Caenis, Baetidae, Ceratopogonidae, and Tropisternus were negatively correlated. 

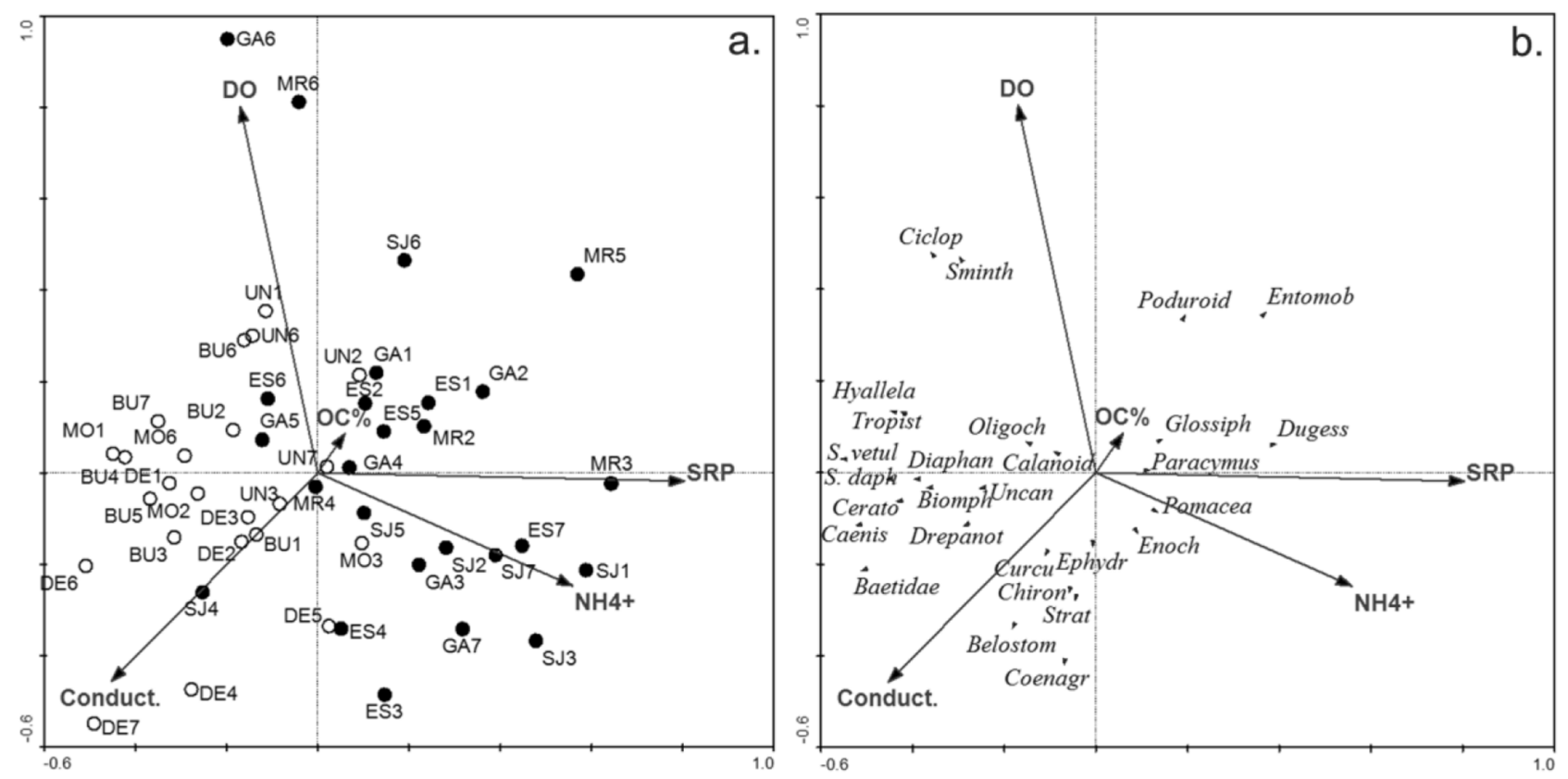

Fig. 2. Partial-RDA Analysis. Biplots of environmental data and samples (a) and species (b). Filled circles, horticulture-adjacent streams; white circles, less-disturbed streams. Stream names: SJ, San Juan; MR, Martin; GA, Gato; ES, Sauce; UN, unnamed; BU, Buñirigo; MO, Morales; DE, Destino. Sampling dates: 1, Oct-2014; 2, Dec-2014; 3, Jan-2015; 4, Mar-2015; 5, May-2015; 6, Oct-2015; 7, Dec-2015.Taxa: Baet, Baetidae; Belost, Belostoma; Biomph, Biomphalaria; Calan, Calanoidea; Cerato, Ceratopogonidae; Chiro, Chironomidae; Ciclop, Ciclopoidea; Coena, Coenagrionidae; Curcu, Curculionidae; Diaph, Diaphanosoma; Drepa, Drepanotrema; Dugess, Dugessidae; Enoch, Enochrus; Entomo, Entomobryoidea; Ephy, Ephydridae; Glossiph, Glossiphonidae; Hyal, Hyalella sp.; Oligo, Oligochaeta; Paracy, Paracymus; Poduro, Poduroidea; Poma, Pomacea; S. daph, Simocephalus daphnoides; S. vet, S. vetulus; Sminth, Sminthuroidea; Strat, Stratiomyidae; Uncan, Uncancylus. Only the variables that significantly explained the macroinvertebrate assemblage are shown.

\section{Discussion}

Higher nutrient concentrations in streams associated with horticulture suggest the occurrence of a leaching of fertilizers applied to the crops from the ground into the adjacent streams. High nutrient concentrations at sites adjacent to agricultural plots have been repeatedly reported. Arbuckle and Downing (2001), studying the relationships between agricultural land use and the N:P ratio in Iowa lakes, found that the TN/TP was positively correlated with agriculture and negatively so with grasslands. Figueiredo et al. (2010) demonstrated that the conversion of land use from grasslands to agriculture increased nitrate concentrations in streams where crops bordered the stream margins. Mugni et al. (2013) measured higher nutrient concentrations in a stream surrounded by a recently fertilized crop than in the same stream when that crop was not being fertilized. The nutrient concentrations in the present study revealed a wide variability, likewise reported in previous publications (e.g., Mugni et al., 2013; Solis et al., 2016, 2017).

The present results on the detection of insecticides in horticulture-associated streams were consistent with the findings reported the literature. Kammerbauer and Moncada (1998) studied several freshwater systems - i.e., rivers, wells, and lagoons - adjacent to agricultural and horticultural land uses in Honduras; the horticulture-impacted water samples exhibited a higher number of pesticides detected and a greater detection frequency than the agriculture-related samples. Mac Laughlin et al. (2017) reported high and frequent concentrations of chlorpyrifos (up to $2258 \mathrm{ng} / \mathrm{g} \mathrm{dw}$ ) and pyrethroids (e.g., lambda-cyhalothrin at $649 \mathrm{ng} / \mathrm{g} \mathrm{dw}$ ) in bottom sediments of the Carnaval Stream located within the horticulture area studied in this work.

The pesticide concentrations measured and the higher detection frequency in the horticulture-associated streams in the present study suggest a contribution from the adjacent crops. The pattern registered was consistent with endosulfan concentrations measured in the air in the same area, reported by Astoviza et al. (2016): The maximum air concentrations were recorded in an orchard in Olmos, between the Sauce and Gato streams; while the minimum were reported in a livestock basin in Magdalena, located near the less-disturbed streams sampled in this study. The occasional pesticide detection at low concentrations in the less-disturbed streams is consistent with the long-range atmospheric transportation of those compounds from the application sites that has been previously reported (Weber et al., 2010). The pesticide concentration detected in the less-disturbed streams might conceivably be also contributed by applications associated with cattle-pest control within the livestock areas surrounding the reserve. Cypermethrin and chlorpyrifos are frequently used for such a purpose (Ferré et al., 2018), typically to combat the horn-fly pest in cows (Oyarzún et al., 2008).

The taxonomic richness and density were positively correlated with macrophyte cover. Several authors reported that macrophyte complexity was associated with a high abundance and richness of macroinvertebrates (Walker et al., 
2013; Ferreiro et al., 2014). We thus employed a partial-RDA analysis subtracting the effect of vegetation to enable us to refine the assessment of the macroinvertebrate assemblage in relation to land use per se.

The different macroinvertebrate-assemblage composition together with the lower richness and density of the taxa present in the horticulture-associated streams suggested that those changes had resulted from pesticide exposure. Simocephalus vetulus and Hyalella sp. were the dominant taxa in the less-disturbed streams. The Daphniidae are the most common cladocera used in biomonitoring because of their sensitivity to pesticides (Zhou et al., 2008). Simocephalus vetulus - a cosmopolitan cladocera species among the Daphniidae that is associated with aquatic vegetation in eutrophic systems - is extensively used as a model organism for toxicity testing (Willis et al., 1995; Chen et al., 2004; Schroer et al., 2004). Similarly, amphipods of the genus Hyalella have repeatedly been used as monitoring organisms (Nebeker and Miller, 1989). Mugni et al. (2011) reported toxicity to Hyalella curvispina of runoff and the water in the Sauce stream at a site near to the present study sites in coincidence with the first rain following pesticide application to an adjacent crop. Toxicity to $H$. curvispina in runoff water from experimental soy plots after chlorpyrifos, endosulfan, and cypermethrin application followed by rain simulations was likewise documented by Paracampo et al. (2012). Mac Laughlin et al. (2017) reported sediment toxicity to $H$. curvispina in the Carnaval Creek, where the lowest survival and growth rates were registered in coincidence with the highest insecticide concentrations. The Ephemeroptera and Trichoptera have often been considered in indices and metrics for assessing environmental quality (Barbour et al., 1999), typically being featured in the EPT - Ephemeroptera, Plecoptera, and Trichoptera - index. The taxa Caenis, Hydroptilidae, Polycentropodidae, and Decapoda - considered sensitive by Liess and Von der Ohe (2005) - were found in only the less-disturbed streams in the present study. In addition, Suren (1994), in Nepal, recorded a high abundance of Baetidae in grassland-associated streams while being poorly represented in those adjacent to agriculture.

In contrast, the Entomobryoidea, Dugessidae, and Glossiphoniidae were well represented at the present horticultureaffected sites and their presence accordingly correlated with the nutrient concentrations in the multivariate analysis, thus indicating a relation to horticultural land use. The Dugessidae and Glossiphoniidae were considered by Liess and Von der Ohe (2005) to be tolerant to pesticides. Similarly, Egler et al. (2012), studying water quality and macroinvertebrate composition in relation to forest, pasture, and intensive agricultural land use in Brazil, recorded a higher abundance of Collembola accompanying elevated nutrient concentrations together with a lower taxa richness in the agricultural streams. Wang et al., (2016) reported that the addition of both organic (soybean cake) and inorganic fertilizers in poplar plantations likewise increased the abundance of collembolans in soil and considered that finding to be a result of increased food availability.

The elevated nutrient concentrations in the horticultureassociated streams might conceivably affect macroinvertebrate assemblages by enhancing the phytoplankton biomass. No significant changes in the chlorophyll content, though, were detected among the different land uses. Water turbidity and/or competition with macrophytes for light and nutrients might, however, limit phytoplankton growth. In the present study, multivariate analysis suggested the combined effect of simultaneous incorporation of nutrients and pesticides through runoff following crop applications to be responsible for the positive correlation of the tolerant taxa and negative association of the sensitive taxa with elevated nutrient concentrations. Malacarne et al. (2016), in Brazil, studying the composition of aquatic macroinvertebrates and the kinetics of leaf-litter breakdown in streams with different land uses (i.e., urban, agriculture, and preserved forested areas), documented a higher richness and diversity in the lessdisturbed streams. Consistent with our results, sensitive macroinvertebrates were found in only those less-disturbed streams, with that community being significantly different from agriculture- and urban-associated assemblages. Similarly, Fierro et al. (2017) - investigating invertebrate assemblages at sites in Chilean rivers that were adjacent to native forest, forest plantation, and agricultural land uses - reported higher nutrient concentrations and a lower macroinvertebrate richness and diversity in the locations associated with agricultural catchments than those affected by other land uses. Because our observations in horticulture-related streams were similar to those reported above in water bodies adjacent to agricultural basins, the agrochemicals employed in both land-use activities in the present work were presumably responsible for the similar effects.

\section{Conclusions}

Macroinvertebrate assemblages and stream-water quality are affected by horticultural land use in the adjacent plots in the Buenos Aires province of Argentina. Fertilizers and pesticides reach nearby streams, increasing nutrient concentrations and altering macroinvertebrate composition. Horticulture-associated streams exhibited assemblages of tolerant taxa along with a lower taxonomic richness and density. Hyalella sp., Simocephalus vetulus, Baetidae, and Caenis sp. - considered taxa sensitive to insecticide exposure - are absent or present at low densities in those horticulture-affected streams, while were well represented in the less-impacted ones. In contrast, Dugessidae, Glossiphoniidae, and Entomobryioidea - considered comparatively tolerant taxa - were dominant in the streams adjoining horticulture. The composition of macroinvertebrate assemblages thus represents a reliable indicator for analyzing land use in lowland streams. We therefore propose $S$. vetulus and Hyalella sp. - those being common and abundant macroinvertebrates in the environments of this region that are, for their part, highly sensitive to pesticides - to be reliable indicators of the impact of pesticides on the water bodies in this area.

\section{Supplementary Material}

Supplementary Table S1.

The Supplementary Material is available at https://www.kmaejournal.org/10.1051/kmae/2019048/olm. 
Acknowledgements. This research was funded by the National Scientific and Technical Research Council (CONICET; PIP $2011 \mathrm{~N}^{\circ}$ 0180) and the Argentine National Agency for the Promotion of Science and Technology (ANPCyT; PICT 2010 0446). We acknowledge the anonymous reviewers for valuable suggestions and comments. Dr. Donald F. Haggerty, a retired academic career investigator and native English speaker, edited the final version of the manuscript.

\section{References}

Allinson G, Bui AD, Zhang P, et al. 2014. Investigation of 10 herbicides in surface waters of a horticultural production catchment in Southeastern Australia. Arch Environ Contam Toxicol 67: 358-373.

APHA. 2012. Standard Methods for the Examination of Water and Wastewater, 22nd edition. Washington DC: American Public Health Association.

Arbuckle KE, Downing JA. 2001. The influence of watershed land use on lake N:P in a predominantly agricultural landscape. Limnol Oceanogr 46: 970-975.

Astoviza MJ, Cappelletti N, Bilos C, Migoya MC, Colombo JC. 2016. Massive airborne Endosulfan inputs related to intensive agriculture in Argentina's Pampa. Chemosphere 144: 1459-1466.

Athor J, ed. 2009. Parque Costero del Sur - Naturaleza, conservación y patrimonio cultural. Fundación de Historia Natural "Félix de Azara", Buenos Aires 562 p.

Barbour MT, Gerritsen J, Snyder BD, Stribling JB. 1999. Rapid bioassessment protocols for use in streams and wadeable rivers: periphyton, benthic macroinvertebrate s and fish, 2nd Edition. EPA 841-B-99-002. Washington DC: U.S. Environmental Protection Agency, $337 \mathrm{p}$.

CASAFE. 2013. Cámara de Sanidad Agropecuaria y Fertilizantes. Buenos Aires, Argentina. Available at: http://www.casafe.org/ publicaciones/estadisticas/ [Accessed: 10/12/2017].

Chen CY, Hathaway KM, Folt CL. 2004. Multiple stress effects of Vision ${ }^{\circledR}$ herbicide, ph, and food on zooplankton and larval amphibian species from forest wetlands. Environ Toxicol Chem 23: 823-831.

CHFB. 2005. Censo Horti-Florícola Bonaerense. Ministerio de Asuntos Agrarios y Ministerio de Economía, Secretaria de Agricultura y Ganadería. Available at: http://www.estadistica.ec. gba.gov.ar/dpe/Estadistica/chfba/censohort.htm [Accessed: 20/4/ 2018].

CIAFA. 2017. Cámara de la Industria Argentina de Fertilizantes y Agroquímicos. Informe sobre Evolución de la Agricultura y uso de Fertilizantes. Available at: http://www.ciafa.org.ar/info-fertili zantes-informes [Accessed: 10/12/2017].

Clarke KR, Gorley RN. 2001. PRIMER v5: User Manual/Tutorial. Plymouth: PRIMER-E, $192 \mathrm{p}$.

Clarke KR, Warwick RM. 2001. Change in marine communities: an approach to statistical analysis and interpretation, 2nd ed. Plymouth: PRIMER-E, $172 \mathrm{p}$.

Dethier MN, Graham ES, Cohen S, Tear LM. 1993. Visual versus random-point percent cover estimations: 'objective' is not always better. Mar Ecol Prog Ser 96: 93-100.

Domínguez E, Fernández HR eds. 2009. Macroinvertebrados bentónicos. Sistemática y biología, 1 ed (In Spanish) Fundación Miguel Lillo, Tucumán 656 p.

Egler MA, Buss DF, Moreira JC, Baptista DF. 2012. Influence of agricultural land use and pesticides on benthic macroinvertebrate assemblages in an agricultural river basin in southeast Brazil. Braz $J$ Biol 72: 437-443.

FAO. 2013. Statistical Year Book, World Food and Agriculture. Food \& Agriculture Organization. Available at: http://www.fao.org/ docrep/018/i3107e/i3107e.PDF [Accessed: 10/12/2017].

Ferré DM, Quero AAM, Hernández AF, et al. 2018. Potential risks of dietary exposure to chlorpyrifos and cypermethrin from their use in fruit/vegetable crops and beef cattle productions. Environ Monit Assess 190: 292.

Ferreiro N, Feijoo C, Giorgi A, Rosso J. 2014. Macroinvertebrates select complex macrophytes independently of their body size and fish predation risk in a Pampean stream. Hydrobiologia 740: 191-205.

Fierro P, Bertrán C, Tapia J, et al. 2017. Effects of local land-use on riparian vegetation, water quality, and the functional organization of macroinvertebrate assemblages. Sci Total Environ 609: 724-734.

Figueiredo RO, Markewitz D, Davidson EA, Schuler AE, Watrin OS, de Souza Silva P. 2010. Land-use effects on the chemical attributes of low-order streams in the eastern Amazon. J Geophys Res 115: G4.

Friberg-Jensen U, Wendt-Rasch L, Woin P, Christoffersen K. 2003. Effects of the pyrethroids insecticide, cypermethrin, on a freshwater community studied under field conditions. I. Direct and indirect effects on abundance measures of organisms at different trophic levens. Aquat Toxicol 63: 357-371.

Hart MR, Quin BF, Nguyen ML. 2004. Phosphorus runoff from agricultural land and direct fertilizer effects: a review. J Environ Qual 33: 1954-1972.

Hurtado MA, Gimenez JE, Cabral MG, eds. 2006 Análisis ambiental del partido de La Plata: Aportes al ordenamiento territorial, 1ra ed. Consejo Federal de Inversiones, Buenos Aires, $125 \mathrm{p}$.

Jergentz S, Mugni H, Bonetto C, Schulz R. 2004. Runoff-related endosulfan contamination and aquatic macroinvertebrate response in rural basins near Buenos Aires, Argentina. Arch Environ Contam Toxicol 46: 345-353.

Jergentz S, Mugni H, Bonetto C, Schulz R. 2005. Assessment of insecticide contamination in runoff and stream water of small agricultural streams in the main soybean area of Argentina. Chemosphere 61: 817-826.

Kammerbauer J, Moncada J. 1998. Pesticide residue assessment in three selected agricultural production systems in the Choluteca River Basin of Honduras. Environ Pollut 103: 171-181.

Kreuger J, Graaf S, Patring J, Adielsson S. 2008. Pesticides in surface water in areas with open ground and greenhouse horticultural crops in Sweden. Ekohydrologi 117, 49 p.

Liess M, Schäfer RB, Schriever CA (2008) The footprint of pesticide stress in communities - species traits reveal community effects of toxicants. Sci Total Environ 406: 484-490.

Liess M, von der Ohe PC. 2005. Analyzing effects of pesticides on invertebrate communities in streams. Environ Toxicol Chem 24: 954-965.

Lorenzen CJ. 1967. Determination of chlorophyll and phaeopigments: spectrophotometric equations. Limnol Oceanogr 12: 343-346

Mac Loughlin TM, Peluso L, Marino D. 2017. Pesticide impact study in the peri-urban horticultural area of Gran La Plata, Argentina. Sci Total Environ 598: 572-580

Malacarne TJ, Baumgartner MT, Moretto Y, Gubiani ÉA. 2016. Effects of Land Use on the Composition and Structure of Aquatic Invertebrate Community and Leaf Breakdown Process in Neotropical Streams. River Res Appl 32: 1958-1967. 
Merrit RW, Cummins KW, Berg MB, eds. 2008). An Introduction to the Aquatic Insects of North America. Kendall-Hunt, Dubuque, Iowa, $1158 \mathrm{p}$.

Mottes C, Lesueur-Jannoyer M, Le Bail M, Guéné M, Carles C, Malézieux E. 2017. Relationships between past and present pesticide applications and pollutions at a watershed outlet: The case of a horticultural catchment in Martinique, French West Indies. Chemosphere 184: 762-773.

Mugni H, Ronco A, Bonetto C. 2011. Insecticide toxicity to Hyalella curvispina in runoff and stream water within a soybean farm (Buenos Aires, Argentina). Ecotoxicol Environ Saf 74: 350-354.

Mugni H, Paracampo A, Bonetto C. 2013. Nutrient concentrations in a pampasic first order stream with different land uses in the surrounding plots (Buenos Aires, Argentina). Bull Environ Contam Toxicol 91: 391-395.

Nebeker AV, Miller CE. 1989. Use of the amphipod crustacean Hyalella azteca in freshwater and estuarine sediment toxicity tests. Washington, DC: U.S. Environmental Protection Agency. EPA/ 600/J-88/299 (NTIS PB89202239)

Olivier H, Lotter AF, Lemcke G. 2001. Loss on ignition as a method for estimating organic and carbonate content in sediments: reproducibility and comparability of results. J Paleolimnol 25: 101-110.

Oyarzún MP, Quiroz A, Birkett MA. 2008. Insecticide resistance in the horn fly: alternative control strategies. Med Veter Entomol 22: 188-202.

Paracampo AH, Mugni HD, Demetrio PM, et al. 2012. Toxicity persistence in runoff and soil from experimental soybean plots following insecticide applications. $J$ Environ Sci Health B 47: $761-768$

Relyea R. 2004. Synergistic impacts of Malathion and predatory stress on six species of North American tadpoles. Environ Toxicol Chem 23: 1080-1084.

Rimoldi F, Peluso L, Bulus Rossini G, Ronco EA, Demetrio PM. 2018. Multidisciplinary approach to a study of water and bottom sediment quality of streams associated with mixed land uses: Case study Del Gato Stream, La Plata (Argentina). Ecol Indic 89: 188-198.

Sarandón SJ, Flores CC, Abbona E, et al. 2015. Análisis del uso de agroquímicos asociado a las actividades agropecuarias de la Provincia de Buenos Aires. In: Relevamiento de la utilización de Agroquímicos en la Provincia de Buenos Aires - Mapa de Situación e incidencias sobre la salud. Defensoría del Pueblo de la Provincia de Buenos Aires, 18-495 p. Available at: https://www. defensorba.org.ar/bibliotecavirtual/ [Accessed: 10/12/2017].

Schäfer RB, Caquet T, Siimes K, Mueller R, Lagadic L, Liess M. 2007. Effects of pesticides on community structure and ecosystem functions in agricultural streams of three biogeographical regions in Europe. Sci Total Environ 382: 272-285.

Schäfer RB, von der Ohe CP, Rasmussen J, et al. 2012. Thresholds for the effects of pesticides on invertebrate communities and leaf breakdown in stream ecosystems. Environ Sci Technol 46: $5134-5142$
Schroer AFW, Belgers JDM, Brock TCM, Matser AM, Maund SJ, Van den Brink PJ. 2004. Comparison of laboratory single species and field population-level effects of the pyrethroid insecticide $\lambda$-cyhalothrin on freshwater invertebrates. Arch Environ Contam Toxicol 46: 324-335.

Schulz R. 2001. Rainfall-induced sediment and pesticide input from orchards into the Lourens River, Western Cape, South Africa: importance of a single event. Water Res 35: 1869-1876.

SENASA. 2011. Servicio Nacional de Sanidad y Calidad Agropecuaria. Resolución 511/2011. Available at: http://www.senasa. gob.ar/normativas/resolucion-511-2011-senasa-servicio-nacionalde-sanidad-y-calidad-agroalimentaria [Accessed: 20/4/2018].

Solis M, Mugni H, Hunt L, Marrochi N, Fanelli S, Bonetto C. 2016. Land use effect on invertebrate assemblages in Pampasic streams (Buenos Aires, Argentina). Environ Monit Assess 188: 539.

Solis M, Mugni H, Fanelli S, Bonetto C. 2017. Effect of agrochemicals on macroinvertebrate assemblages in Pampasic streams, Buenos Aires, Argentina. Environ Earth Sci 76: 180.

Solis M, Bonetto C, Marrochi N, Paracampo A, Mugni H. 2018. Aquatic macroinvertebrate assemblages are affected by insecticide applications on the Argentine Pampas. Ecotoxicol Environ Saf 148: $11-16$.

Suren AM. 1994. Macroinvertebrate communities of streams in western Nepal: effects of altitude and land use. Freshw Biol 32: 323-336

ter Braak CJF, Smilauer P. 1998. CANOCO Reference Manual and User's Guide to Canoco for Windows: Software for Canonical Community Ordination (ver. 4). Microcomputer Power, Ithaca, NY, $352 \mathrm{p}$.

Walker PD, Wijnhoven S, van der Velde G. 2013. Macrophyte presence and growth form influence macroinvertebrate community structure. Aquat Botany 104: 80-87.

Wang S, Chen HYH, Tan Y, Fan H, Ruan H. 2016. Fertilizer regime impacts on abundance and diversity of soil fauna across a poplar plantation chronosequence in coastal Eastern China. Sci Rep 6: 20816.

Weber J, Halsall CJ, Muir D, et al. 2010. Endosulfan, a global pesticide: a review of its fate in the environment and occurrence in the Arctic. Sci Total Environ 408: 2966-2984.

Willis KJ, Ling N, Chapman MA. 1995. Effects of temperature and chemical formulation on the acute toxicity of pentachlorophenol to Simocephalus vetulus (Schoedler, 1858) (Crustacea: Cladocera). NZ J Mar Fresh 29: 289-294.

You J, Weston DP, Lydy MJ. 2004. A sonication extraction method for the analysis of pyrethroid, organophosphate, and organochlorine pesticides from sediment by gas chromatography with electron-capture detection. Arch Environ Contam Toxicol 47: 141-147.

Zhou Q, Zhang J, Fu J, Shi J, Jiang G. 2008. Biomonitoring: An appealing tool for assessment of metal pollution in the aquatic ecosystem. Anal Chim Acta 606: 135-150.

Cite this article as: Arias M, Scalise A, Solis M, Paracampo A, Indaco M, Fanelli S, Mugni H, Bonetto C. 2020. Horticulture affects macroinvertebrate assemblages in adjacent streams (Buenos Aires, Argentina). Knowl. Manag. Aquat. Ecosyst., $421,5$. 